\title{
Innovation of Water Harvester Based On Thermoelectric Condenser Using Smart Solar Panel, Ultraviolet Neon Filter and Mineralization System
}

\author{
Moh. Malik Afandi ${ }^{1, a}$, Aulia Husada B. ${ }^{1, b}$, Putria Widya Budiarti ${ }^{1, c}$, Feby Agung Pamuji ${ }^{1, d}$
}

\begin{abstract}
Water is an element which very important in human living requirements. A person can live without food up to a week, but can't live without water a day. In case, water is the foundation of live for human and a country. The availability of water in the world is unlimited, but the water that fulfils the requirement for human consumption is limited. Of the total amount of water available, only 0.3 per cents of it is available as drinking water, the rest is sea water. In Indonesia, with population up to 200 million people, the availability of water is the national issue. Approximately, 119 million Indonesian people don't have an access for clean water yet. The resident of Indonesia whom can access for the clean water is only 20 per cents total of Indonesian people or in the uptown district. It means that 80 per cents Indonesian people obliged to consume water that not fulfils the standard of clean water. The tendency of consuming clean water approximately increases 15-35 per cents per capita for a year. On the other side, the availability of water is decreasing every year because the natural damage and environmental pollution. Through the eco water harvester program, a hope for the people who live in drought areas to get clean water is open widely. This technology utilizes innovation process based on thermoelectric air condensation and equipped with power supply using solar panels and ultraviolet neon filter technology.
\end{abstract}

Keywords - Condenser, Harvester, Thermoelectric, Ultraviolet, Water.

\section{INTRODUCTION}

$\mathrm{W}$ ATER is an element which very important in human living requirements. The availability of water is unlimited, but water that fulfils the requirement for human consumption is limited. From the total amount of water available, only 0.3 per cents of it is available as drinking water, the rest is sea water. Unfortunately, the availability of water is decreasing day by day. The increasing of population means that the demand of water is increase too, with result that the availability of water is decreasing [1].

Based on 2010 World Health Organization (WHO) data, approximately there are two billion peoples affected by the crisis of water availability per day in more than 40 countries in the world. Over 1.1 billion people don't have sufficient

\footnotetext{
a ,d Department of Electrical Engineering, ${ }^{b}$ Department of Environmental Engineering, ${ }^{\mathrm{C}}$ Department of Engineering Physics

${ }^{1}$ Sepuluh Nopember Institute of Technology, Sukolilo ITS Campus 60111, Surabaya, Indonesia
}

water and 2.4 billion peoples don't have good sanitation. In 2050 WHO predicted that one of four people will affect the impact from the lack of water [2].

In Indonesia, with population up to 200 million people, the availability of water is one of the national issues. Approximately, 119 million Indonesian people don't have an access for clean water yet. The resident of Indonesia whom can access for the clean water is only 20 per cents total of Indonesian people or in the uptown district. It means that 80 per cents Indonesian people obliged to consume water that not fulfils the standard of clean water. The tendency of consuming clean water approximately increases $15-35$ per cents per capita for a year. On the other side, the availability of water is decreasing every year because the natural damage and environmental pollution [3].

On the other side, Indonesia was nations that have high humidity level of air up to 80 per cent average [4]. The high air humidity level is potentially for harvesting water with condensation phenomena. From thus condition a product of harvesting water with condensation process based on high air humidity level is indispensable. Eco Water Harvester (EWH) is a device that can convert the air to water by condensation process. EWH have three main components. The first one is Eco Condenser. Eco Condenser made by thermoelectric with two heat sinks and two fans. The first heat sink is for heat absorber and the second one is for cold side. The second one component is Green Energy Supply. Green energy supply consists of solar panel with solar tracker methods, automatic voltage controller and battery. The last one is Blue Water Filter. This filter consists of neon ultraviolet filter and mineralization system of calcium $\left(\mathrm{CaCO}_{3}\right)$ and magnesium $\left(\mathrm{Mg}(\mathrm{OH})_{2}\right)$.

\section{MATERIALS AND METHODS}

\subsection{Thermoelectric Device}

Thermoelectric is a device that produces electricity energy from Seebeck effect. Seebeck effect is when there is two metals with different pole connected by it point, then given difference temperature in it connection. The different temperature produces difference voltage of the other side [5]. When thermoelectric given a difference voltage, it produces difference temperature from the layers. The cold side layers temperature and the hot side layers temperature. The cold 
side layer will be used for condenser to make water from air humidity.

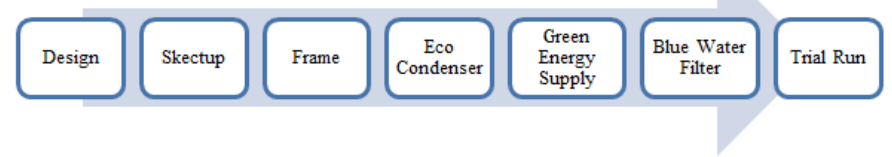

Fig. 1 Flowchart Methods to Make Eco Water Harvester

\subsection{Smart Solar Panel}

Solar panel is an electricity generation device that consists of diodes. The conversions of solar energy to electricity energy in solar panel occur though photovoltaic process which depends on sunlight radiation. The peak power of solar panel will obtained if the module vertically with the direction of sunlight. Some of solar panels have a maximum efficiency number up to $10 \%$ with $22 \mathrm{~W} / \mathrm{m}^{2}$ power average [6].

A Photovoltaic (PV) panel usually consists of a series and parallel interconnection of a number of PV panel cells, which converts the solar radiation to electrical energy. The electrical characteristics of a solar panel under temperature and solar irradiance variation are manifested in the output current and voltage. Effective control of the PV source terminal voltage maintains a value such that the product of PV voltage and current achieves a maximum value, known as the maximum power point (MPP) [7]. In this paper, we used smart solar panel to achieve maximum value of the solar panel electric power. Smart solar panel is a solar panel that use solar tracker [Fig. 2] to develop the voltage dropping when the sunlight radiation not vertically with solar panel module.

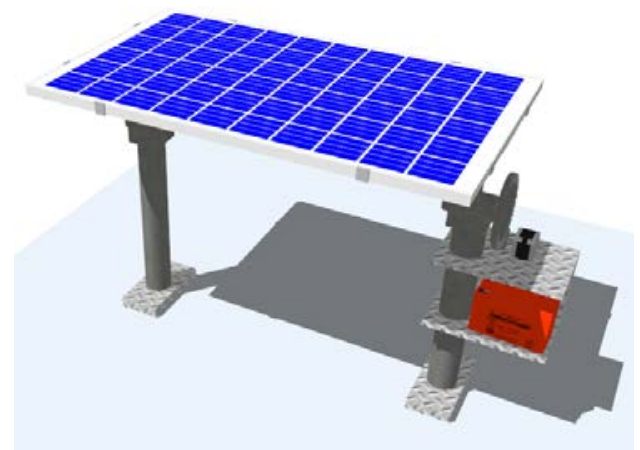

Fig. 2 Design of Green Energy Supply

\subsection{Ultraviolet Neon Filter}

Ultraviolet (UV) ray is a microorganism slayer through this ray that absorbed by it DNA especially in 260-280mm wave or usually called by UV C. There are UV A and UV B that have wavelength up to $280-400 \mathrm{~mm}$, but the effectively is 10 less than UV C [8]. The UV neon with 65 Watt power can process water with 2.5 litres debit per second. To make larger value, the Watt power of neon UV has to be bigger than 65 watt or proportional with the water debit [9]. The ultraviolet neon filter is to make sure that the pathogen bacteria weren't exists anymore or the water was clearly sterile.

\subsection{Mineralization System}

Drinking water that contains few mineral is an extreme soft water because doesn't have major mineral such as calcium and magnesium. Soft water easiest to contamination with bacteria too. Drink thus water have several losses such us direct impact in intestines mucosa membrane, metabolism and mineral homoeostasis. Based on WHO data at 1980, drinking water must have at least $\mathrm{Mg} 10 \mathrm{mg} / \mathrm{L}$ and $\mathrm{Ca}$ $20 \mathrm{mg} / \mathrm{L}$ [10]. In this paper we used step up methods based on Fig. 1.

\section{RESULtS}

Generally this product consists of three main components. The first component is Eco Condenser, an environmentally friendly condenser based on thermoelectric device, heat sink and fan to produce water from air humidity. The second component is a Green Energy Supply, a renewable energy from solar panel equipped with solar tracker to produce high efficiency electricity energy supply. The last component is Blue Water Filter, a filter from neon ultraviolet to slay the pathogen bacteria and mineralization system of $\mathrm{CaCO}_{3}$ and $\mathrm{Mg}(\mathrm{OH})_{2}$. The experiments take in Surabaya, Indonesia. For electricity energy supply, this experiment takes on Electrical Engineering Department. For water contents experiment we take in Environmental engineering laboratory and for the automation system we take in engineering physics department in Surabaya Campus.

\subsection{Eco Condenser}

Eco condenser consists of thermoelectric device, double heat sink (heat absorber and cold absorber) and double fan (cooling booster and air intake). In Indonesia, the air humidity level is high average because Indonesia located in equatorial area. The air humidity level in Indonesia is 80 per cents average. On the other hand, the area that doesn't have water supplied is the humid area and have high intense of sun light.

With dimension of peltier/thermoelectric cool layer $4 \mathrm{~cm} \mathrm{x}$ $4 \mathrm{~cm} \times 0.8 \mathrm{~cm}$, with maximum electric current up to 3.6 Ampere and the difference temperature around 40-50 degree Celsius and air humidity up to 70 per cents average in Surabaya, Indonesia, the solar panel supplied 12 volt electricity for this eco condenser. From our experiment, eco water harvester can produce water up to one litre for an hour [11]. In other way, using eco water harvester can take the water up to eight litres per day with assumption that the solar panel can supplied the electricity energy up to eight hours and have 70 per cents efficiency.

Eco condenser doesn't produce any emission (zero emission). This condenser is different with conventional condenser based on Freon technology that produce CFC gas and make ozone surface depleting.

\subsection{Green Energy Supply}

Green energy supply consists of solar panel equipped with solar tracker, automatic solar panel regulator and battery. The specification of solar panel is $50 \mathrm{Wp}$ (watt peak) and the battery capacity is 50 Ah with 12 volt. In this program we choose solar panel because solar panel is zero emission (environmentally friendly) and have more aesthetic value than the other renewable energy. Else, solar panel doesn't 
need wide space compare with air turbine. Unfortunately, beside there are some areas that doesn't have water supplied, there are still some areas that doesn't have electricity supplied in Indonesia. Furthermore, in dry area there is high intension of sun light bot in summer and in winter season. From our experiment in Surabaya, Indonesia the result of electricity from solar panel generator without solar tracker technology shown on Table 1.

TABLE I

RESUlt OF SOlar PANEL Without SOlar TRACKER MOdULE

\begin{tabular}{|c|r|r|}
\hline Time Zone & Voc (Volt) & Power (Watt) \\
\hline 07.00 & 15.20 & 35.18 \\
\hline 08.00 & 16.50 & 38.19 \\
\hline 09.00 & 18.30 & 42.36 \\
\hline 10.00 & 21.20 & 49.07 \\
\hline 11.00 & 21.40 & 49.53 \\
\hline 12.00 & 21.60 & 50.00 \\
\hline 13.00 & 21.50 & 49.77 \\
\hline 14.00 & 21.00 & 48.61 \\
\hline 15.00 & 20.90 & 48.37 \\
\hline 16.00 & 17.80 & 41.20 \\
\hline 17.00 & 15.00 & 34.72 \\
\hline Average & $\mathbf{1 9 . 1 2}$ & $\mathbf{4 4 . 2 7}$ \\
\hline
\end{tabular}

From that result, there is a voltage drop in some time zone when the module of solar panel didn't vertically direction with radiation of sun light. In this paper, we use solar tracker method to improve electricity energy and decrease dropping voltage. The result of solar panel using solar tracker module is shown on Table 2 .

TABLE II

Result of Solar Panel With SOlar TRacker Module

\begin{tabular}{|c|r|r|}
\hline Time Zone & Voc (Volt) & Power (Watt) \\
\hline 07.00 & 18.50 & 42.82 \\
\hline 08.00 & 19.90 & 46.06 \\
\hline 09.00 & 20.80 & 48.14 \\
\hline 10.00 & 21.60 & 50.00 \\
\hline 11.00 & 21.60 & 50.00 \\
\hline 12.00 & 21.60 & 50.00 \\
\hline 13.00 & 21.60 & 50.00 \\
\hline 14.00 & 21.60 & 50.00 \\
\hline 15.00 & 21.20 & 49.01 \\
\hline 16.00 & 19.80 & 45.83 \\
\hline 17.00 & 18.80 & 43.52 \\
\hline Average & $\mathbf{2 0 . 6 3}$ & $\mathbf{4 7 . 7 6}$ \\
\hline
\end{tabular}

From this result, the improvement of solar panel efficiency is 8 per cents and the working periods of solar panel are longer than solar panel without solar tracker module.
TABLE III

COMPARISON BETWEEN SOLAR PANEL USING SMART SOLAR PANEL WITH CONVENTIONAL SOLAR PANEL

\begin{tabular}{|c|c|c|c|r|}
\hline \multirow{2}{*}{$\begin{array}{c}\text { Time } \\
\text { Zone }\end{array}$} & \multicolumn{2}{|c|}{ Smart Solar Panel } & \multicolumn{2}{c|}{$\begin{array}{c}\text { Conventional } \\
\text { Solar Panel }\end{array}$} \\
\cline { 2 - 5 } & $\begin{array}{c}\text { Voc } \\
\text { (Volt) }\end{array}$ & $\begin{array}{c}\text { Power } \\
\text { (Watt) }\end{array}$ & $\begin{array}{c}\text { Voc } \\
\text { (Volt) }\end{array}$ & $\begin{array}{c}\text { Power } \\
\text { (Watt) }\end{array}$ \\
\hline 07.00 & 18.50 & 42.82 & 15.20 & 35.18 \\
\hline 08.00 & 19.90 & 46.06 & 16.50 & 38.19 \\
\hline 09.00 & 20.80 & 48.14 & 18.30 & 42.36 \\
\hline 10.00 & 21.60 & 50.00 & 21.20 & 49.07 \\
\hline 11.00 & 21.60 & 50.00 & 21.40 & 49.53 \\
\hline 12.00 & 21.60 & 50.00 & 21.60 & 50.00 \\
\hline 13.00 & 21.60 & 50.00 & 21.50 & 49.77 \\
\hline 14.00 & 21.60 & 50.00 & 21.00 & 48.61 \\
\hline 15.00 & 21.20 & 49.01 & 20.90 & 48.37 \\
\hline 16.00 & 19.80 & 45.83 & 17.80 & 41.20 \\
\hline 17.00 & 18.80 & 43.52 & 15.00 & 34.72 \\
\hline Average & $\mathbf{2 0 . 6 3}$ & $\mathbf{4 7 . 7 6}$ & $\mathbf{1 9 . 1 2}$ & $\mathbf{4 4 . 2 7}$ \\
\hline
\end{tabular}

\subsection{Blue Water Filter}

Blue water filter consists of neon ultraviolet filter and mineralization system of Calcium and Magnesium. To improve the efficiency of neon ultraviolet, we use ultrasonic sensor SR-04 to calculate the high level of water. This neon ultraviolet will be turn on when the water level is 0.5 litres. It's mean that the neon ultraviolet will be 30 minutes on and 30 minutes off in one hour periodically. The mineralization system consists of $\mathrm{CaCO}_{3}$ and $\mathrm{Mg}(\mathrm{OH})_{2}$ to make the $\mathrm{H}_{2} \mathrm{O}$ (aquades) from eco condenser fulfil the standard of drinking water.

This filter can decrease pathogen bacteria and make soft mineral water proper to drink. From our experiment, the water contain after filtering with blue water filter is shown in Table 4.

TABLE IV

RESULT OF WATER WITH BLUE WATER FILTER

\begin{tabular}{|c|c|c|c|}
\hline $\begin{array}{c}\text { Parameter } \\
\text { s }\end{array}$ & Unit & $\begin{array}{c}\text { Condensation } \\
\text { Water }\end{array}$ & $\begin{array}{c}\text { Standard } \\
\text { Quality }\end{array}$ \\
\hline $\mathrm{pH}$ & & 7.98 & $6.5-8.5$ \\
\hline Colour & $\mathrm{CU}$ & 15 & 15 \\
\hline Turbidity & $\mathrm{NTU}$ & 5.8 & 5 \\
\hline Nitrate & $\begin{array}{c}\mathrm{mg} / \\
\mathrm{L}\end{array}$ & 1.285 & 50 \\
\hline $\mathrm{E} \mathrm{Coli}$ & $\mathrm{mL}$ & $1 / 100$ & $50 / 100$ \\
\hline $\mathrm{Mg}$ & $\begin{array}{c}\mathrm{mg} / \\
\mathrm{L}\end{array}$ & 10 & 10 \\
\hline $\mathrm{Ca}$ & $\begin{array}{c}\mathrm{mg} / \\
\mathrm{L}\end{array}$ & 20 & 20 \\
\hline
\end{tabular}

\section{Discussion}

In this section, we discuss about the quantity of water, cost ratio and the opportunity of eco water harvester continuance. Generally, a device that doesn't have excess is or have just a little exist (the output doesn't proportional with input/low efficiency device) will not allowed to the market. Furthermore, nowadays a drinking water is a must. Usually, a device that has complicated process is expensive, but eco water harvester device is cheaper than general for sale 
mineral water just like the analysis of the cost benefit ratio section.

\subsection{Water Quality and Quantity}

Based on our experiment, eco water harvester can produce up to eight litres water a day. A person needs two litres to back up the liquid of his body. So, eco water harvester can fulfil the water requirement for one family (four people). We can also have more water by using electricity from electricity concern but that is not the point. We used blue water filter because we make sure that the water is approved to be drinking water. The contents of eco condenser water before filtering with blue water filter is shown on Table 5.

TABLE V

CONTENTS OF WATER BEFORE FILTERING WITH BLUE WATER FILTER

\begin{tabular}{|c|c|c|c|}
\hline Parameters & Unit & $\begin{array}{c}\text { Condensation } \\
\text { Water }\end{array}$ & $\begin{array}{c}\text { Standard } \\
\text { Quality }\end{array}$ \\
\hline $\mathrm{pH}$ & & 7.98 & $6.5-8.5$ \\
\hline Colour & $\mathrm{CU}$ & 15 & 15 \\
\hline Turbidity & $\mathrm{NTU}$ & 5.8 & 5 \\
\hline Nitrate & $\mathrm{mg} / \mathrm{L}$ & 1.285 & 50 \\
\hline E Coli & $\mathrm{mL}$ & $200 / 100$ & $50 / 100$ \\
\hline
\end{tabular}

4.2 Device Power Requirement Analysis and Cost Benefit Ratio

The battery specification is 12 volts with $50 \mathrm{Ah}$, or $600 \mathrm{Wh}$. To charge the battery with a $50 \mathrm{Wp}$ solar panel module we need 12 hours in constant power. Green power supply only has 11 hours to work properly. The conclusion is the battery only has 11 hours supply from solar panel or has $550 \mathrm{Wh}$ power capacity.

The power requirement of thermoelectric is 40 Watt, and the neon ultraviolet is 20 Watt. But, neon ultraviolet is only works half by hour periodically. So, this eco water harvester device needs 50 watt power supply from the battery. The effective time to turn on eco water harvester is at 04.00-08.00 and 14.00-18.00 or eight hours a day when the air humidity level is relatively higher than the other time. So, the power requirement is 400 Watt for a day. This power requirement analysis is shown on Table 6.

TABLE VI

POWER ANALYSIS

\begin{tabular}{|c|c|c|c|}
\hline $\begin{array}{c}\text { Solar Panel } \\
\text { Capacity }\end{array}$ & $\begin{array}{c}\text { Battery } \\
\text { Specification }\end{array}$ & $\begin{array}{c}\text { Total Power } \\
\text { Generation }\end{array}$ & $\begin{array}{l}\text { Device Power } \\
\text { Requirement }\end{array}$ \\
\hline $\begin{array}{c}50 \text { Watt peak } \\
\text { (11 hours and } \\
85 \% \\
\text { efficiency) }\end{array}$ & $\begin{array}{c}12 \mathrm{~V}, 50 \mathrm{Ah} \\
\text { (600Wh) }\end{array}$ & $\begin{array}{l}50 \times 11 \times 85 \% \\
=(467.5 \text { Watt })\end{array}$ & $\begin{array}{l}400 \text { Watt per day } \\
\text { (50 x } 8 \text { hours) }\end{array}$ \\
\hline
\end{tabular}

Based on Table 6, the conclusion is the green power supply can obtain power requirement of the eco water harvester device. With 12 Volt and 50Ah battery, eco water harvester can working up to eight hours.

To build one eco water harvester device is no cheap. The most expensive part is green energy supply. From Table 7, we can see how much to build eco water harvester.
TABLE VII

PRICE TO BUILD ECO WATER HARVESTER

\begin{tabular}{|l|r|r|r|}
\hline \multicolumn{1}{|c|}{ Name } & $\begin{array}{c}\text { Quantit } \\
\text { y }\end{array}$ & \multicolumn{1}{c|}{$\begin{array}{c}\text { Price } \\
\text { (USD) }\end{array}$} & $\begin{array}{c}\text { Total } \\
\text { (USD) }\end{array}$ \\
\hline $\begin{array}{l}\text { Solar Panel } \\
\text { 50Wp }\end{array}$ & 1 & 84 & 84 \\
\hline $\begin{array}{l}\text { Solar Panel } \\
\text { Regulator }\end{array}$ & 1 & 33 & 33 \\
\hline $\begin{array}{l}\text { Battery 12V } \\
\text { 50Ah }\end{array}$ & 1 & 58 & 58 \\
\hline Thermoelectric & 1 & 5 & 5 \\
\hline Neon UV & 2 & 5 & 10 \\
\hline Heat sink & 2 & 5 & 10 \\
\hline Fan & 2 & 2 & 4 \\
\hline Acrylic Body & 1 & 9 & 9 \\
\hline SR-04 & 1 & 4 & 4 \\
\hline $\begin{array}{l}\text { Solar Tracker } \\
\text { Module }\end{array}$ & 1 & 17 & 17 \\
\hline $\begin{array}{l}\text { DC Stepper } \\
\text { Motor }\end{array}$ & 1 & 17 & 17 \\
\hline $\begin{array}{l}\text { Water Level } \\
\text { Module }\end{array}$ & 1 & 5 & 5 \\
\hline \multicolumn{2}{|r|}{ Total Price } & & $\mathbf{2 5 6}$ \\
\hline
\end{tabular}

In Rupiahs the total cost to build eco water harvester is 3.072.000 rupiahs. From our mathematic calculation, the life time of eco water harvester device is 10 years. So, we only need 854 rupiahs for a day to get eight litres water with eco water harvester. If we compare with mineral water that for sale in Indonesia, the cost for 1.5 litres mineral water is 3.000 rupiahs and it just only for one person. If we use eco water harvester we can save 2.146 rupiahs and get 6.5 litres more mineral water than for sale mineral water. Eco water harvester is an alternative solution to overcome drinking water crisis especially in dry and humid area that fulfil the effective conditions to run the device.

\section{CONCLUSIONS}

Eco water harvester is an alternative solution to overcome drinking water crisis especially in dry and humid area that fulfil the effective conditions to run the device. The water content of eco water harvester is clearly safe to be human consuming and fulfil the standard quality of drinking water.

Eco water harvester is use green technology and environmentally friendly such as solar panel, thermoelectric device and neon ultraviolet. Eco water harvester need more cost in the beginning but no need money to operate it.

\section{ACKNOWLEDGEMENTS}

The authors gratefully acknowledge the financial supports of the Sepuluh Nopember Institute of Technology, Surabaya, Indonesia. Academic Disciplines of Engineering Physics, Electrical Engineering and Environmental Engineering Sepuluh Nopember Institute of Technology, Indonesia. 


\section{REFERENCES}

[1] Gamawan, G. 2010. Krisis Air Bersih di Indonesia (Crisis of clean water in Indonesia). Accessed from http://eprints.uny.ac.id/5485/1/

[2] Eole Water, 2011. Water Worldwide. Accessed from http://www.eolewater.com /gb/news/learn-about-water.html

[3] Yuliastuti, Dian. 2011. 30 Penyakit Ini Akibat Krisis Air Bersih (this 30 diseases, because lack of clean water). Accessed from http://www.tempo.co/read/news/2011/09/07/060354927/30-Penyakit-Ini-Akibat-Krisis-Air-Bersih

[4] Anonim. 2009. Kelembaban dan Penguapan Udara (air humidity level and evaporating). Accessed form http://www.serdangbedagaikab.go.id/indonesia/

[5] Sik Han, Hun et al. 2010. Performance Measurement and Analysis of a Thermoelectric Power Generator. IEEE Journal, ITherm 12th, page.1-7.

[6] Azevedo GMS, Cavalcanti MC, Oliveira KC, Neves FAS, Lins ZD. 2008. Evaluation of maximum power point tracking methods for grid connected photovoltaic system. Proceeding of IEEE power electronics specialists conference. http://dx.doi.org/10.1109/pesc.2008.4592141

[7] Zhou, Z., Holland P.M., Igic P. 2014. MPPT Algorithm Test on a Photovoltaic Emulating System Constructed by a DC Power Supply and an Indoor Solar Panel. Sciencedirect Journal. College of Engineering, Swansea University, Singleton Park, Swansea SA2 8PP, UK.

[8] Tortora, Funke, and Case. 2010. Microbiology : an Introduction. New York : McGraw-Hill.

[9] Hanovia. 2010.

[10] Kozisek, Frantisek. 2013. Health Risks From Drinking Demineralized Water. National Czech Republic Journal Chapter 12.

[11] Afandi, Moh Malik. Budiarti, Putria Widya, Husada, Aulia Bhakti. 2014. Innovation of Water Harvester using Thermoelectric Device to Overcame Clean Water Crisis in Indonesia Dry Area. Semarang State University Journal Proceedings IPC 2014. 